Article

\title{
At Home with Durga: The Goddess in a Palace and Corporeal Identity in Rituparno Ghosh's Utsab
}

\section{Romita Ray}

Department of Art and Music Histories, Syracuse University, 308 Bowne Hall, Syracuse, NY 13244, USA; E-Mail: rray@syr.edu; Tel.:+1-315-443-5030

Received: 6 January 2014; in revised form: 4 February 2014 / Accepted: 7 February 2014 /

Published: 31 March 2014

\begin{abstract}
In this article, I examine the representational strategies used to visualize the pratima (deity) of the Hindu goddess, Durga, as a paradigm of time, memory, and corporeal identity, in Rituparno Ghosh's 2000 Bengali film Utsab. I analyze the body as a dynamic site of memory-formation that shapes new histories in the sprawling colonial palace in which the film's narrative unfolds with an ancestral Durga festival as its focal point. To this end, I look at how the body of the goddess produces and defines the transience of human experience, the fragility of material history, and the desire for historic relevance.
\end{abstract}

Keywords: Calcutta; colonial; body; Durga; goddess; jewelry; memory; palace; puja; Rituparno Ghosh

\section{Introduction}

Rituparno Ghosh's award-winning 2000 Bengali movie Utsab (The Festival) [1] begins by invoking the Hindu goddess Durga during the annual Durga festival [2] in a historic rajbari (palace) near Kolkata [3] ${ }^{1}$. What interest me here are the representational strategies Ghosh uses to visualize the pratima (deity) as a paradigm of time, memory, and corporeal identity for a once prosperous family

\footnotetext{
1 This article is dedicated to my late maternal grandmother Bidyutkana Pal (a Bhagabati in her own right) and to my mother Arundhati Ray whose family tradition of Durga puja was sadly discontinued in 1991. For their help at various stages of researching and writing this article, I thank my parents, Meenakshi Ghosh (née Mitra), and Rita Bhimani in Kolkata, Pratapaditya and Chitralekha Pal in Los Angeles, and the two anonymous reviewers of this manuscript. Sadly, Rituparno Ghosh died on 30 May 2013 shortly before his fiftieth birthday.
} 
forced to cope with the exigencies of modernity. While the interplay between the past, present, and future ensures that the body is a dynamic node of memory-formation, the sprawling colonial residence in which the film's narrative unfolds is central to the encodings of memory. As such, the pratima and the palace are inextricably linked through the "lived" experience of architecture, a complex palimpsest of corporeal identities, historical change, cultural referents, and psychological and sensory responses distilled into powerful sites of memory in the ebb and flow of time. Be it the pratima or the palace, each reinforces the other's historicity, each resists death, and each verifies the density of ancestral heritage. But as the film progresses, it becomes clear that both are on the verge of becoming obsolete as the family copes with their dwindling financial resources. And in their impending obsolescence lies the disturbing prospect of the loss of identity and belonging.

Celebrated during the autumn season, Durga puja is the most popular Hindu festival in Bengal, its splendor transforming public and private spaces (especially in Kolkata) into what Anjan Ghosh calls "a very public festival" [4], including erstwhile zamindari celebrations promoted today as tourist attractions [5]. The focal point of these festivities is the icon of the goddess Durga vanquishing the demon Mahishãsura disguised as a buffalo (Figure 1). The principal figure amid an assemblage of five deities, Durga is flanked on either side by her four children: Lakshmi, the goddess of wealth; Saraswati, the goddess of knowledge; Ganesh, the god who bestows success; and Kãrtik, the god of courage.

Figure 1. Sri Sri Durgamata [6].

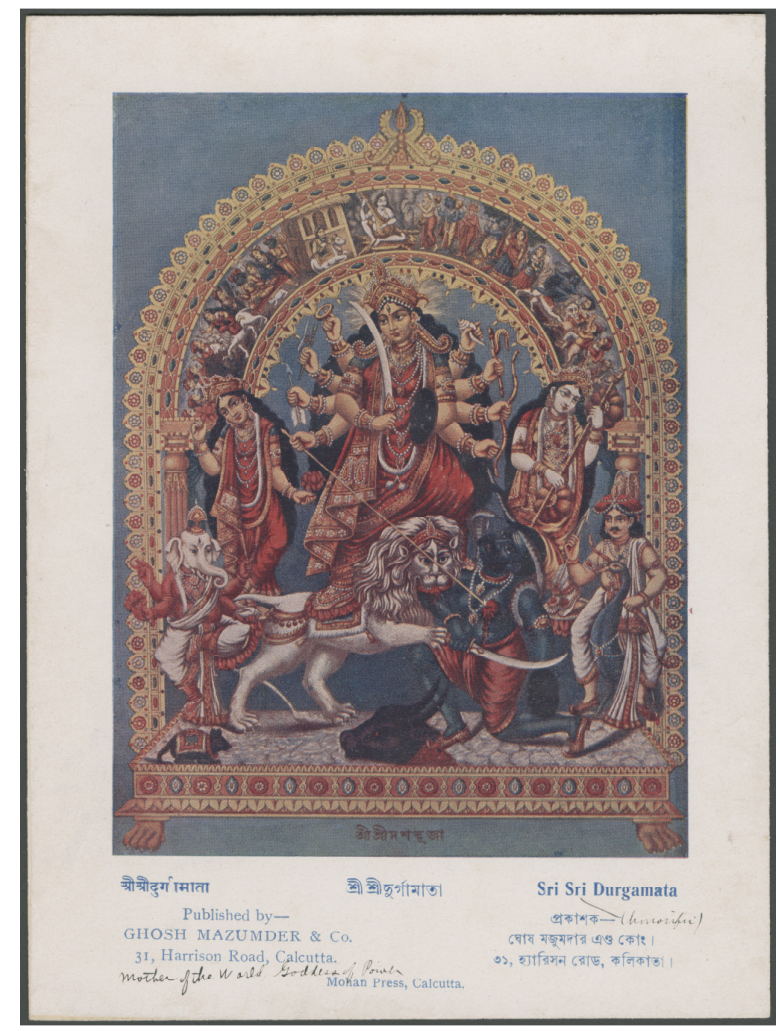

This powerful combination of a warrior goddess and a nurturing mother takes on the additional layer of a married daughter when Durga is welcomed back home in the earthly realm during her puja [7]. By the time she returns to her husband Shiva's Himalayan abode at the festival's end, Durga 
is venerated as both a deity and a populist icon in the tide of popular visual culture that saturates the public domain for at least a month in advance of her festivities (Figure 2).

Figure 2. Advertisement for the State Bank of India featuring the goddess Durga [8].

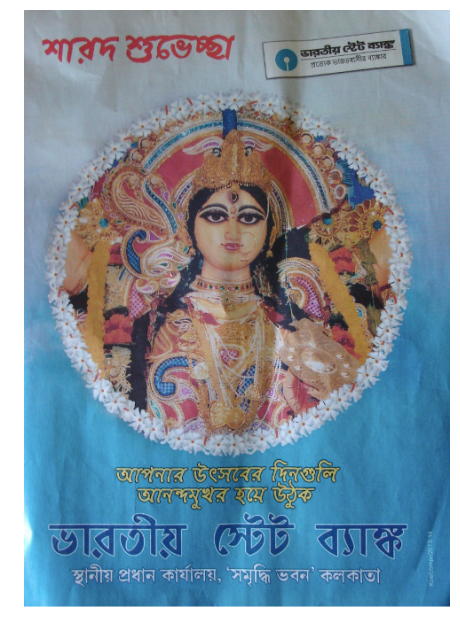

Keeping in mind the centrality of the Durga pratima, I look at how Durga puja transforms a domestic setting into a living spectacle of ancestral heritage in Utsab. But what does it mean to have the goddess "present" at home? Sculpture, borrowing from Yi-Fu Tuan, has "the power to create a sense of place by their own physical presence." [9]. A deity or a pratima takes this idea further by articulating the sacredness of time and place, albeit only temporarily during the puja. Once the festivities cease, the boundaries between sacred and secular geographies dissolve, and the palace returns to its incarnation as a full-fledged domestic realm. It goes without saying that the temporary thresholds created during Durga puja hinge upon the desire to forge a sense of historic continuity, a longing made visible, above all by the Durga pratima. The corporeality of the goddess thus engenders the lived-out cultural experience of the festival, while also re-arranging the spatial and social landscapes of a home. In Utsab, the spectacle of the pratima is articulated by both the deity's iconic presence within the cinematic frame and its palpable absence from the screen, urging us to think about how the very processes of viewing and veneration are entangled with the power of iconography. In her study of contemporary Durga festivals in Kolkata, Tapati Guha-Thakurta observes that Durga puja has emerged as a "new kind of ritual site" where "viewing and wonderment" appear to "supplant worship." ([7], pp. 56-57). It is precisely this fluid and untidy experience of aesthetics and sacredness that Ghosh invokes in Utsab, albeit within the context of a domestic festival in a rajbari. As Guha-Thakurta suggests, the contemporary visitor to a Durga puja is at times, more akin to a tourist in a museum than to a devotee in a temple. Armed with his video camera, Joy, one of the principal characters of Utsab, exemplifies such a visitor for whom the pratima is as much a cinematic subject and an object of curiosity as she is a family deity and a sacred body.

Here, I wish to draw attention to two overlapping corporealities embodied by the pratima: first we have the material body of clay and paint that constitutes the murti (sculpture), and next, the symbolic and indeed, imagined presence of Ma Durga or Mother Durga that gives meaning to the consecrated pratima. Moreover, we have a living parallel to the goddess in the lead character of the film, Bhagabati-the elderly matriarch played with a deft touch by the eminent Bengali actress Madhabi Mukherjee. Suspended between these two powerful female protagonists, one mythical (Durga) and the 
other living (Bhagabati), Utsab weaves its way through the tensions of living up to the gravitas of ancestry and lineage, while blurring the boundaries between the sacred and the secular, and between mythology and the dynamic realms of human belief and experience. Bhagabati's Durga is a family deity sequestered in the depths of a historic palace, not unlike the matriarch herself. The similarities between the maternal Durga and Bhagabati do not end here. Like Durga, Bhagabati has two sons and two daughters whose trials and tribulations shape the film's narrative.

Such an interplay between the realm of lived (meaning human) experience and the lives of the gods, brings me to Rachel Dwyer's observation that Indian cinema "is the place" that unites "the modern and the religious, in a way that is often viewed as secular." [10]. Yet, as Dwyer and more recently, Sheila Nayar, have observed, very little has been written about the contours of religion in Indian movies [11]. If gods occupy screen space, so too does devotion, faith, and an unerring belief in divine providence fleshed out in the film's characters and cinematography. For Ghosh, devotion cuts across multiple spheres centered on the goddess Durga, be it the historic past of Bhagabati's family or the process of filmmaking itself. Taking my cue from Dwyer and Nayar, in this article, I look at how he harnesses the technologies of the video or film camera to underscore the corporeal, social, and psychic identities mediated by the pratima, identities that bring together religious faith, family history, and patriotic pride in the messy trajectory of everyday lived experience. What we need to keep in mind is that in Utsab, the pratima belongs to the colonial past as much as it does to the post-Independence present. Corporeality is therefore embedded in a dense network of temporalities whose overlaps and fissures challenge the viewer to think about what Steven Lubar and the late William David Kingery describe as a "history from things", an archaeology of the past in which prized artifacts embody patterns of cultural flows and fluctuations [12]. Enter the rajbari and its contents with which the pratima is inextricably linked.

What patterns are articulated by Bhagabati's pratima in a colonial palace? Not only has the rajbari borne witness to multiple generations of family history registered by the family deity, it is also a testament to the collective loss the family must face with Bhagabati's demise. First, I look at how the bejeweled goddess articulates the weight of the colonial past when Bhagabati's family made their fortune and Bengali womanhood was redefined by nationalist agendas. Next, I examine how the pratima is staged as a paradigm of ancestral pride and decline by deploying the architecture of the colonial rajbari and the widowed figure of Bhagabati. If spatial and corporeal identities attest to the endurance of devotion, then how do they resist the limitations of the biological body? It is by juxtaposing the fixity of an ancestral icon with the transience of human corporeality that Ghosh accentuates the tensions between time, space, and a living tradition. Such a preoccupation with continuity and how it is challenged by the losses ushered through death, underscores the last theme I examine in the final section of my article where I look at how Ghosh flirts with the possibility of immortalizing himself by embedding the Durga pratima, a quintessential icon of Bengali heritage and filmmaking, in Utsab.

\section{The Bejeweled Pratima}

In the opening frames of Utsab, the camera pans across a magnificent chandelier hanging overhead (Figure 3). The close-up view of the ornate yet brittle canopy of crystal together with the voice-over 
narration of Joy, Bhagabati's grandson and a budding filmmaker, draw our attention to the transient grandeur of the rajbari whose fading glory is entangled with the family's Durga pratima. As the camera focuses on the chandelier, we hear Joy describing the jewels imported from Germany that once adorned the family deity. But the glittering body of the goddess invoked by the ornamental spectacle of an expensive European domestic fixture, is fundamentally a clay icon sculpted and painted by a local artisan. Moreover, like the chandelier, it is testament to Bengal's prosperous mercantile past when landowning families like Bhagabati's had grown immensely wealthy from their collaborations with the English East India Company in the eighteenth and nineteenth centuries, and whose taste for European luxuries and furnishings had resulted in what Supriya Chaudhuri (by way of Walter Benjamin's analysis of commodity culture) calls "phantasmagorias of the interior." [13]. In the context of the contemporary era, however, the pratima and the chandelier are poignant vestiges of the desire to hold onto a glittering past in the midst of declining fortunes [14]. Equally striking is the loss of a cosmopolitan veneer that these nineteenth-century relics represent in sharp contrast to the unmistakably middle-class status to which Bhagabati and her descendants have been reduced.

Figure 3. Chandelier from the opening sequence, screen grab, Utsab [1].

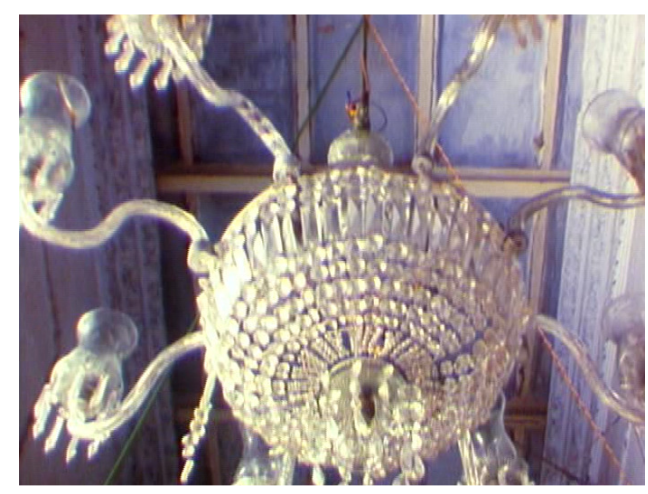

The pratima's jewels invoke other corporeal identities as well that not only reveal taxonomies of luxury and pleasure, but also what Marcia Pointon calls "the disruptive character of precious stones." [15]. From the middle of the nineteenth century onwards, European jewelry, cosmetics, shoes, petticoats, and blouses were de rigueur among a select group of wealthy, westernized, fashion-conscious bhadramahila (genteel woman) [16-19] like Sunity Devi, Maharani of Cooch Behar and daughter of the renowned social reformer Keshub Chunder Sen, who was frequently portrayed as a Victorian—not just a Bengali--woman in paintings and photographs made by well-known Victorian English artists and photographers like Sydney Prior Hall (Figure 4) [20]. While Sunity Devi was being fêted by Victorian artists in London, closer to home in Calcutta, the eminent author, educationist and song writer Sarala Devi, a member of the renowned Tagores of Jorasanko, recalled visiting Hamilton and Company, the famous jewelers and silversmith whose shop at Court House Street saw a steady influx of Indian royals, zamindars, British, and European clients [21]:

'Come with me to the Hamiltons,' he told me. 'Grandfather has asked me to buy you some jewellery within a thousand rupees. ...At Hamiltons, we found nothing suitable within the budget amount, and so we went to another jeweller. There I selected a set comprising a diamond and ruby necklace and a pair of matching bracelets [22]. 
Figure 4. Sydney Prior Hall, The Maharani of Cooch Behar [20].

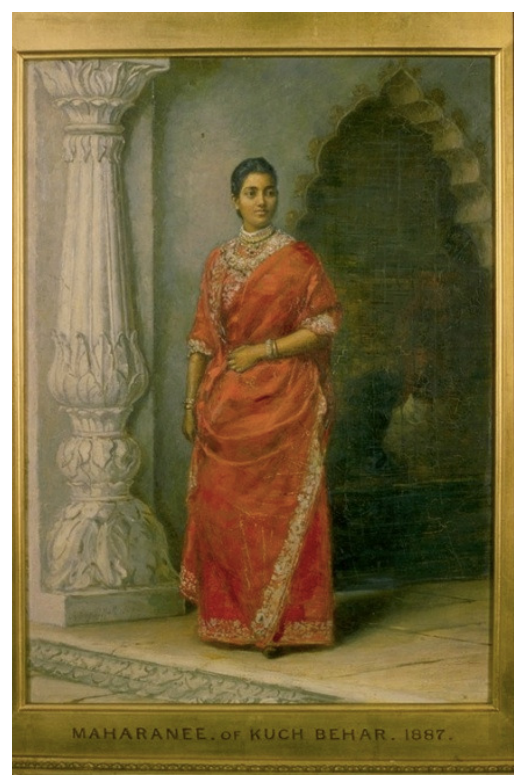

But not everybody endorsed such choices. Bengali critics and moralists lampooned and condemned the taste for European commodities, their castigations underscoring fears about changing social divisions triggered by the emergence of a new Bengali mercantile elite who had prospered from their collaborations with the English East India Company. What is striking is that many of these fears converged upon the changing body of the modern Bengali woman ([16], p. 625). As early as 1823, Bhabanicharan Bandyopadhyay wrote disparagingly of Calcutta's Durga puja as "a festival of chandeliers, lamps, poets, nautch girls, or even of the wife's ornaments and clothes." [23]. In his Paribarik prabandha (Essays on the Family) published in 1882, Bhudev Mukhopadhyay criticized the "hankering for the external glitter and ostentation of the English way of life" ([16], p. 625), while the patriotic playwright and poet Mukunda Das encouraged Bengali women to "smash" their "(imported) glass bangles." [24]. As Tanika Sarkar observes, "foreign goods, habits, and fashions" were perceived as corrupting a woman's body, and by extension, a quintessentially Bengali way of life in which the woman was identified and indeed mythologized as a "life giver and live preserver." ([24], p. 2013). Close contact with European norms and social habits in a colonial city meant that Bengali men had to adjust to the demands of those points of contact, prompting them to assert a new level of patriarchal control over the woman's body. In dress, character, food, and religious devotion, the Bengali woman was therefore expected to maintain a level of cultural and spiritual purity that their male counterparts struggled to sustain ([16], p. 629).

With the rising patriotic fervor in Bengal, such strident expectations of femininity were bolstered by the rhetoric of nationalism, crystallizing into the patriotic figure of Bharat Mata or "Mother India." An idealized construction of womanhood who in Partha Chatterjee's words, embodied "self-sacrifice, benevolence, devotion, religiosity, and so on", Bharat Mata may have glorified the complex myth of a woman's "strength and power," but in reality, she wrote out a woman's ability to exercise the full potential of her social, cultural, and political agency ([16], p. 630; [25,26]). Moreover, as Jasodhari Bagchi contends, the popularity of goddess worship in Bengal enabled her idealized figure to flourish ([25], pp. WS66-WS70). From this perspective, the Durga pratima can be read as a powerful 
appropriation from the material, mythical, and visual realms of sacred iconography whose signage of divine motherhood was firmly entrenched in patriarchal expectations of femininity. Not surprisingly, with Calcutta's growing ranks of rich Bengali compradors, the pratima was lodged in lavish displays of wealth amassed by members of the very same patriarchy who were stalwarts of the city's colonial Bengali elite.

The frontispiece in Charles Coleman's 1832 study, The Mythology of the Hindus depicts one such pratima bedecked in precious gems and jewels [27] (Figure 5). Adorning the pratima became the stuff of urban legend as eminent patriarchs competed with each other to embellish the spectacle of their family deities. Keeping this in mind, Joy's reference to jewels from Germany might have been inspired by the iron, railway, and coal magnate Shib Krishna Daw (Da) of Jorasanko whose family pratima was ornamented with a profusion of jewelry imported from Europe (differing accounts indicate that the jewels were purchased in Paris and Germany), priceless accouterments that were carefully removed before the goddess was immersed in the river at the festival's end ([23], pp. 34-35; [28]). In sharp contrast, upon "prince" Dwarkanath Tagore's orders, the pratima at the neighboring Tagore household was famously immersed with all her gold ornaments intact in a flamboyant attempt to eclipse the Da family's prosperity ([23], pp. 91-92, endnote no. 7; [28], p. 939). Returning to Utsab, the opulence of German jewelry, the crystal resplendence of a European chandelier, or for that matter, the neoclassical grandeur of the palatial house, reveal the extent to which the taste for European luxuries and architectural styles had also made its way into zamindari and nawabi mansions situated outside of Calcutta [29].

Figure 5. Charles Coleman, Frontispiece from The Mythology of the Hindus [27].

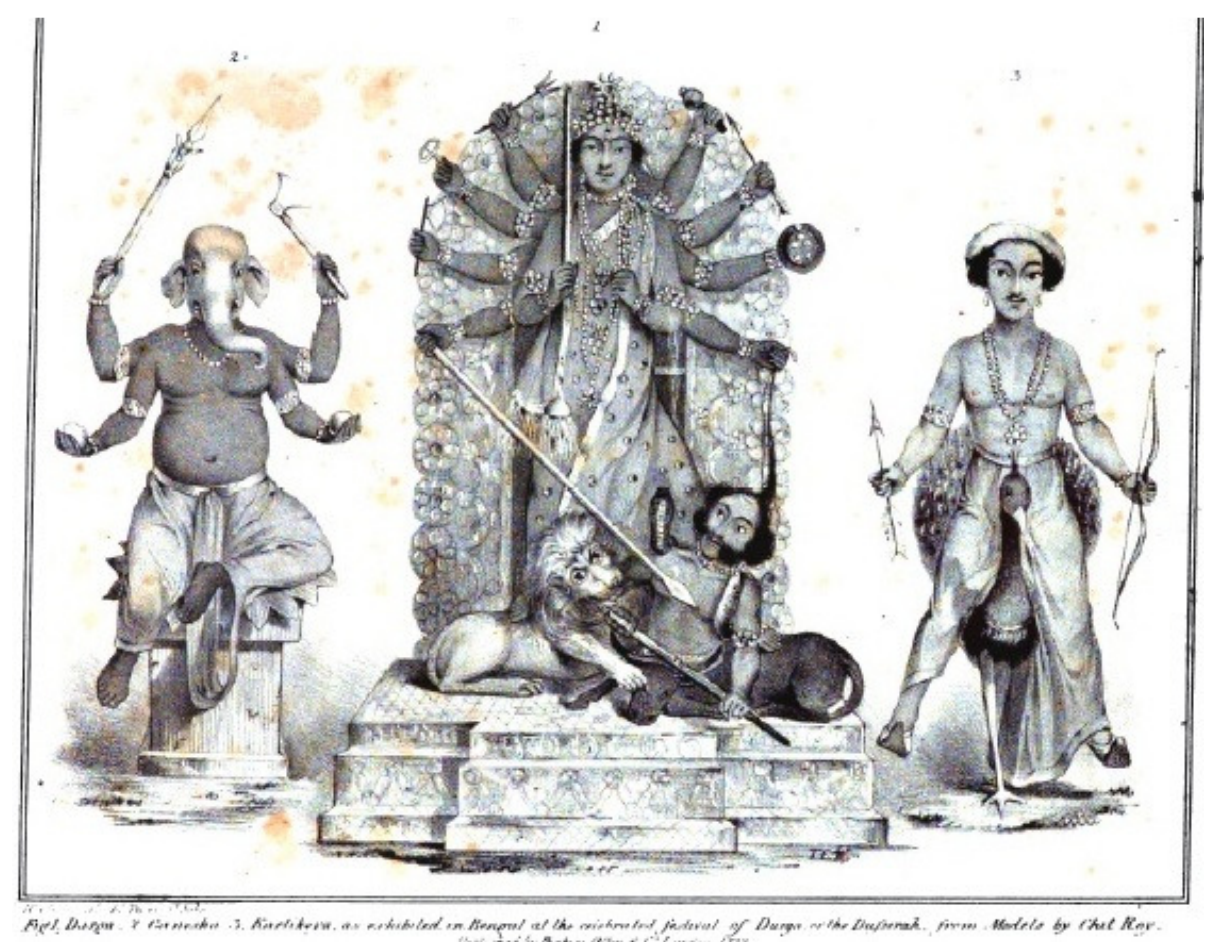

Cultural referents to an ostentatious past that conflicts with the family's current middle-class existence, such details, however, are not simply material signposts that trigger nostalgia along the lines of what bell hooks calls "a useless act," a sentimental journey down memory lane in which the desire 
to resurrect the past is carried out through a superficial recital of its material fragments [30]. Rather, nostalgia is embedded in the tension of grappling with those fragments, of trying to reconcile with a past whose material reality in the present is a financial burden, a point of emotional angst, and a threshold of psychic dislocations. Joy's video camera-wielding figure documenting the house during the course of Durga puja is more akin to a tourist who singles out objects like the chandelier as museum curiosities, a far cry from a family member at ease with the domestic bric-a-brac of his lived spatial experience. Such an uneasy engagement with space and time forces us to confront the desire to forge a sense of shared identity through material artifacts dotting the expanse of the domestic interior, even in the absence of a meaningful connection between objects and the individuals linked to them.

As such, it is the video camera that orchestrates that process of anchoring a shared family identity in what is no longer a joint or extended family in which aunts, uncles, cousins, and grandparents live under the same roof. In fact, Ghosh's entire movie begins and ends with Joy's family video as if to reiterate that belonging is always tenuous and fragile, and can only be affirmed when the main cast of characters involved in a circuit of shared identity are compelled to review their relations with each other, their puja, and their home. What better way to do this than to create a family video? Seen another way, if the video camera embeds the desire to affix and thus endorse a shared heritage marked by cherished possessions and traditions, it simultaneously highlights a past radically split from the material reality of its present. While the very making of a family video foreshadows a narrative of decline, the deployment of a video camera embodies the desire to preserve memories, spaces, objects, and family traditions that might soon be obliterated because the palace is on the brink of being sold. In effect, the video reveals the desire to preserve a sense of cohesion in a family fragmented into nuclear units, their lives lived out for the most part not in the mansion but in Kolkata. The only character in the film to inhabit the rajbari year-round is Bhagabati whose widowed figure clad in white (the visual opposite of a resplendent pratima) is a vision of fading glory not unlike the house itself [31]. In her fragility lies the quiet yet constant reminder that her death will usher in another death of sorts-the end of Durga puja as an ancestral tradition.

Within this context of death and decline, jewelry emerges as a powerful trope of loss whose negotiations frame different registers of corporeal identity that in turn embody fluctuating wealth. German jewels may have once adorned the family's pratima, but when Bhagabati's youngest daughter-in-law Monica offers to sell her gold jewelry to solve her husband's financial troubles, we are aware that a different economic reality has settled in. Not only does the bejeweled body represent financial security, it is also capable of inscribing immense wealth while endorsing a convincing spectacle of power. Once removed from the material reality of the body, however, and consigned to the fantasy world of myth and legend, jewelry can also signify great loss. It is precisely this dialectic between glittering ostentation and eroded power that underscores Bhagabati's tattered family fortune, the sharp contrast between the once bejeweled pratima and the prospect of selling family jewels (and that too, by a rich daughter-in-law) further heightens the poignancy of loss. And it is in the loss of wealth that Ghosh compels us to chart the loss of family belonging, heritage, and history.

Indeed, such narratives of decline are not uncommon among several Bengali banedi (aristocratic) families who still celebrate Durga puja with a traditional pratima even though they no longer enjoy the financial footing they once had, beginning with the descendants of the Bengali zamindar Sabarna Roy Choudhury who still dutifully perform their ancestral puja in their crumbling thakur dalan at 
Barisha [32] (Roy Choudhury famously granted the East India Company the precious land that became Calcutta, in the seventeenth century) [33]. Still others have abandoned their annual celebrations of Durga puja altogether. Like the Roy Choudhurys, wealthy Bengalis in the emerging capital of the British Raj established Durga puja as an annual family tradition while competing with each other for well-known European visitors to their festivities (Gobindaram Mitra of Kumartuli, Shovabazar's Nabakrishna Deb, and Pathuriaghata's Nilmani and Baisnabdas Mallik, among several others, issued open invitations in local British newspapers) ([33], pp. 41-44). As we have already seen, these compradors also competed over the splendor of their bejeweled pratimas. If their extravagance endorsed a trail of urban fictions, then the poignancy of loss cuts deep because such fictions remain locked in the past. No current scenario comes close to producing colorful myths, and to this end, the corporeality of the deity has been divested of the claims to fame and fortune it once articulated for these families (and in turn, Bhagabati's). It is in this limited scope or the financial incapacity to produce fantastical visions of wealth and status that the pratima now mediates the banal versus the extraordinary, signaling the transformation of banedi taste into a more muted, if not mundane trajectory of consumption.

\section{A Goddess in Absentia}

If jewelry accentuates the family pratima as a site of competing wealth and family pride, then how does a bejeweled goddess in absentia articulate a family's history? In Utsab, architecture frequently mediates between the pratima's absence from the cinematic frame and material reminders of Durga's iconography that ensure the goddess's "presence" as an imagined or symbolic entity. At another level, Ghosh harnesses the dialectic between the absent goddess and her iconic visibility to narrate key points in the family's history, starting with the opening scene that I have already discussed, in which Joy describes his family's Durga puja as a revered ancestral tradition while a crystal chandelier fills the screen as a metonymic reminder of the bejeweled pratima. That such connections are forged in the absence of Durga's icon from the cinematic frame reveals that the pratima is embedded in the deeply imbricated trajectories of family history, devotion, aesthetics, material culture, and taste that underscore the family's commitment to their Durga puja as an unbroken tradition. Just a passing reference to the pratima is, therefore, enough to instill pride in a history spread across several generations. By the same token, just a glimpse of the chandelier sets the tone for the pratima's puja. Most importantly, the deity's unchanging form underscores the pratima as an ancestral deity, not just a family icon, whose constancy affirms a faithful adherence to duty while also bestowing an aura of gravitas upon the family's lineage.

Key to forging a convincing impression of ever-lasting luxury, power, and influence, such gravitas when skillfully maneuvered could transform merchants into maharajas. Eliminate the ancestral icon, and that impression, that gravitas falls apart. Thus, the desire to hold onto Durga puja, and indeed, to replicate the pratima's form time and time again, can be read as the need to sanctify power by bestowing something magical and, therefore, ungraspable upon a heritage built upon mercantile wealth. Thus, the deity gives the vagaries of human ambition a sacred makeover, the fixity of Durga's image stabilizing the constancy of status and power even as the splendor of Durga puja transforms the messy, quotidian taxonomies of wealth accumulation into a divinely sanctioned privilege. For a clay 
figure to effectively elevate the political status, social agency, and cultural clout of its living patrons necessitates corporeal identities be locked into clear-cut, recognizable equations, as say, for instance, between devotee and goddess, and priest and pratima. Within this framework, the performance of privilege becomes integral to affirming power and status. And it is to this end that Durga puja with its staggering array of sacred artifacts and rituals strategically supplants the patina of commerce with the resplendence of royalty. Lacking the historical background and splendor of the maharajas, nawabs, and emperors of India whose chronicles pre-dated the British colonial presence in the subcontinent, and whose iconographies of power were sharpened by myths of divinely sanctioned kingship, elaborate sacred rituals, and brilliantly bejeweled and brocaded bodies over several generations, Bengal's zamindars and new urban "rajas" had to invent their own sacred traditions, myths, and visual propaganda [34]. For this they needed tangible loci that could spatialize their performances of power and influence. Enter the ancestral Durga pratima, her puja, and darshan (viewing) in a sprawling colonial palace.

Within these tightly controlled spaces and spectacles of invented tradition, Ghosh gives us an exception to the unchanging pratima, yet again in absentia. This would be the murti modeled as Bharat Mata upon the orders of a rebellious ancestor (Joy's great-grandfather) whose decision prompted the British government to strip the rebel of his title of "Rai Bahadur." The incident is narrated just as Ghosh frames the scalloped arch of the doorway leading into an uthon (courtyard), a threshold that heightens our expectations of catching a glimpse of the pratima about whom we have heard so much already, but who remains to be seen (Figure 6).

Figure 6. Scalloped arch with sola (pith) decorations strung across, screen grab, Utsab [1].

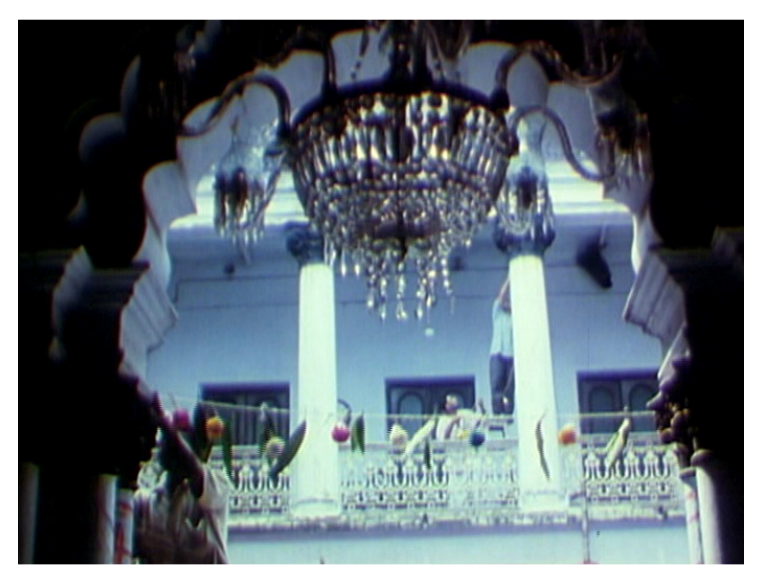

Just as the chandelier draws attention to the invisible pratima, so too does the arch whose outlines echo the shape of the chala (frame) that sits behind the murti (Figure 1), its scalloped edges accentuated by Ghosh's deft modulation of light and shadow. Whether he intended to or not, Ghosh emphasized the power of iconography [35]; specifically, its capacity to summon the image of the pratima with the help of subtle yet familiar contours associated with the ek chala (single frame) deity [36]. Thus, the icon is as much a body that can be imagined, as it is a figure, a tangible murti shaped out of clay that is palpably present in the material realm of lived experience [37].

Even so, the cinematic moment pulls in opposite directions: on the one hand we have a pratima that represents an unbroken tradition (the ek chala Durga) and on the other, the deviant Bharat Mata 
image. That both forms can be invoked simultaneously reveals the complexity of the scopic regime within which the pratima establishes the family's pedigree. As complex layers of iconography specific to Bhagabati's Durga crystallize from fascinating details about the pratima's image, the family's banedi background suitably infused with a touch of patriotic eccentricity also comes to light. Jewelry from Germany, a deity once sculpted as Bharat Mata, and the traditional icon of an ek chala pratima (the Bharat Mata deviation notwithstanding) collectively bind together multiple generations who have conducted the family's Durga puja and left their individual mark on the pratima. If one specific sign of an unchanging icon can be singled out, then it must surely be the ek chala, which, as Joy reminds us, typified the Durga pratimas of landed joint families. More to the point, the ek chala sanctions the shared heritage a joint family represents. As a semi-circular arch, it focuses our attention on Durga as a mother surrounded by her children. It also frames the unmistakable parallel between the joint family and the assemblage of deities that comprise the Durga pratima.

When we finally see the pratima in Utsab, we are introduced to Durga's iconography by way of Banshida the sculptor who explains the panoply of gods to Bumba, Bhagabati's youngest grandchild: "of the four children, Ganesha is the oldest;" he is everybody's "Borda" (older brother), "Lakshmi is the middle child", and so forth (Figure 7). In effect, the gods/goddesses are mapped out as family and are therefore rendered accessible through familiar names and terms of endearment reserved for family members. Significantly, the chala is maneuvered into place while Banshida describes it as a roof that shelters Durga and her family, an observation that relies on familiar details of domestic architecture to situate Durga as a domestic goddess in a child's imagination (Figure 8). Ghosh emphasizes the intimacy of domesticity by ensuring that Banshida, Bumba, and a random helper/servant share the same screen space as the Durga pratima, their figures tightly packing the frame. At a deeper level, Banshida's explanation brings to mind the rajbari itself, a house whose fate is intimately entwined with the destiny of Bhagabati's family. Take away the chala and the pratima's iconography is incomplete, a stark reminder of what might befall Bhagabati and her descendants should their house be sold. Not only do such cinematic gestures harness the full visual scope of the pratima to draw a parallel between a devout Bhagabati and the goddess, they also emphasize the fragile dialectic between the house and its occupants.

Figure 7. Bumba and Banshida, screen grab, Utsab [1].

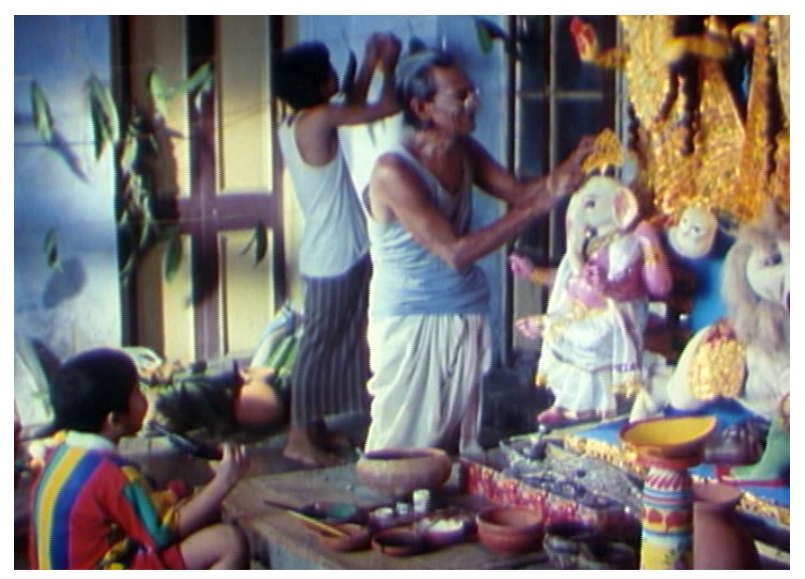


Figure 8. Chala being maneuvered into place, screen grab, Utsab [1].

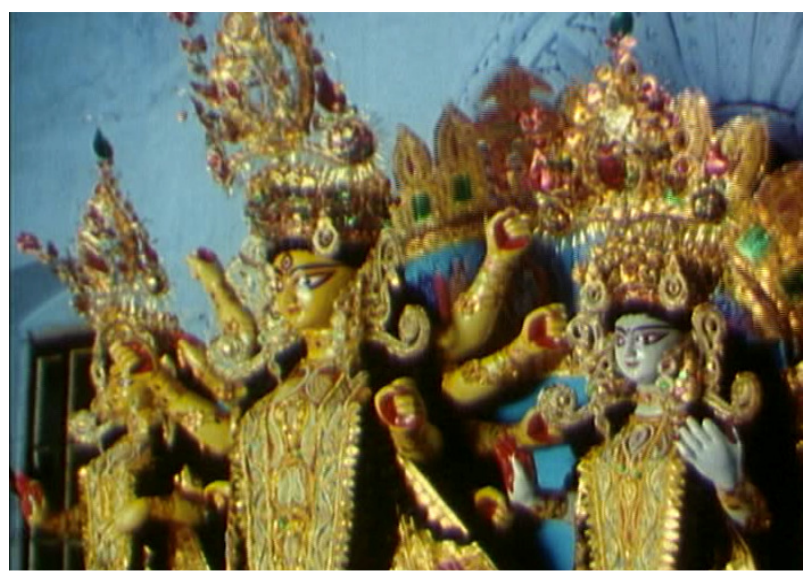

When Bumba inquires if Durga's children are married, Banshida responds that Kãrtik is a bachelor, and Lakshmi and Saraswati are visiting their maternal home without their respective spouses. Yet again, the home emerges as the point of convergence for different family members, which, in Utsab translates into the nucleus of intersections and overlaps that intensify during the festival: who attends the puja and who does not draws the viewer into the private, untidy worlds of emotions of the filmic characters whose individual pasts cast long shadows of misgivings, regrets, and reconciliations. As Keya Ganguly points out in her study of Satyajit Ray's 1960 Devi (a film that also revolves around the goddess Durga, and whose aesthetics are invoked by Ghosh as I discuss later), the "dialectic of history only attests to the wholesale petrifaction of social relations." [38]. As key points of vulnerability surface in the lives lived out on the screen, Utsab hovers on the precarious threshold of dissolution. Relations are tested and often left unresolved. Past loves return only to be sublimated again. And desire is masked by seemingly harmless flirting. Like the shaky chala being maneuvered into place, the rajbari and indeed the family itself are portrayed as fragile, their flaws accentuated as they confront the disruptions facilitated by change. The principal node upon which the film pivots, changes continually, unfolds vis-à-vis the constancy of the pratima's form whose fixed iconography offsets the power of change to unsettle and re-arrange identities, social relations, and the rhythms of life.

Change also highlights history as a malleable, unfixed matrix within which human aspirations are writ large. Yet the making of history is also capable of blunting the contours of change, its detours strikingly apparent when the idealized figure of Bharat Mata is drawn into the orbit of Bhagabati's pratima. Grafting Mother India's iconography onto an otherwise unchanging murti not only intensifies Durga's striking image of matriarchal glory, it does so with the full weight of nationalist fervor in Bengal where the holy trinity of mother-goddess-nation crystallized into a powerful site of patriotic sentiment in the last quarter of the nineteenth century [39]. In 1882, the renowned Bengali writer Bankimchandra Chattopadhyay became the first to invoke the country as a mother in his song Vande Mataram ("I salute thee, Mother") penned for his novel, Anandamath. A series of mother goddesses of the past, present, and the future (also in Anandamath), exemplified the quest to liberate Bengal from both Muslim as well as British rule (it is worth noting that the "image of the great mother" is described as "adorned with all ornaments"). Nearly thirty years later, the Irish born Margaret Noble or Sister Nivedita, a disciple of Swami Vivekananda, would pose the question "Mother and motherland-where ends the one and where begins the other"? The answer of course was embedded in the question itself. 
Nivedita would also conflate motherhood and devotion with the prevailing nationalist discourse of the joint family: "the mother of the universe shines forth in the life of humanity, as a woman, as family life, as country." [40]. If, as Nivedita suggests, Durga was the epitome of a mother looking after her extended family, then, as Ghosh reminds us in the film, it is the colonial palace that best endorses the lived presence of Durga and her invocations of a joint family and nationalist spirit, for it is within the sprawling expanse of the house that the material and cultural signposts of the family are imaged and imagined.

Here too, the pratima is integral to the interplay between spatial and social configurations. For it is the goddess that unites different generations of the family together every year in the thakur dalan, a pavilion built specifically for Durga's darshan and rituals. As importantly, the pratima's centrality is emphasized during key moments of the festival when Bumba is made to write Durga's name 108 times and performs anjali (morning prayers) with his cousin Shompa, and when Shompa helps her aunt light lamps for sandhi puja on ashtami (the eighth day of the festival), Joy plays the dhak, and the married women of the house gather to apply sindoor (vermilion) on Durga and on each other on the festival's last day (dashami) [41] (Figure 9).

Figure 9. Sindoor khela (playing with vermilion), screen grab, Utsab [1].

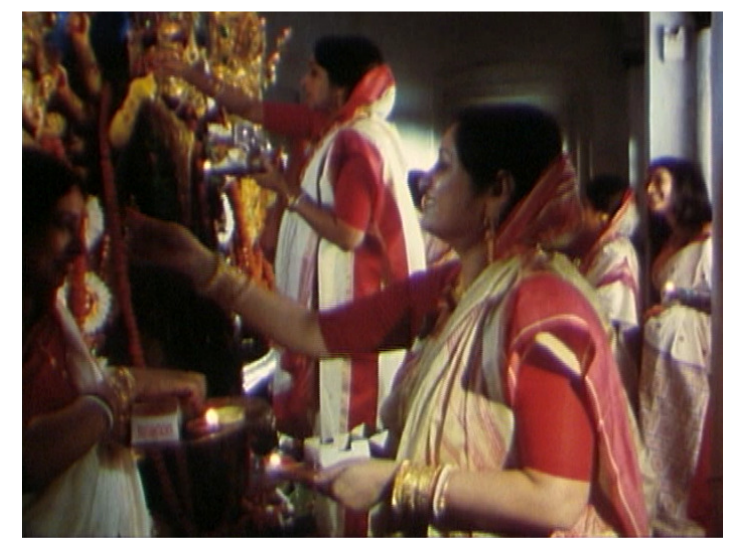

While harmonious visions of the family dutifully participating in the puja's customary rituals in the thakur dalan might convey the impression of protecting and preserving the ancestral pratima and her festivities for posterity, Ghosh also pushes up against those very assertions of continuity for which he, yet again, deploys the pratima's iconography. The icon of Bharat Mata, for instance, imbues the family history with a flare of patriotic pride only to be summarily dismissed by Bhagabati's youngest son-in-law Arun when he mocks the family's contributions to the freedom movement enshrined in trophies and awards displayed in one of the mansion's rooms. Arun's sarcasm targets the very idea of lineage and its tightly woven hierarchies of class and privilege that both the pratima and the palace represent, and the continuum of colonial heritage to which they belong.

Bhagabati's Durga pratima sanctions the continuity of the Durga festival from its earliest incarnation as a colonial puja, itself an appropriation of the rural custom of Durga puja by Calcutta's Bengali elite whose transactions with the Company had resulted in a profusion of wealth and princely titles like "Rai Bahadur" and "Raja." [42,43]. For their part, the Bengali gentry felt the need to display and sustain a visible level of opulence that would convince their British peers and patrons of the worthiness of the princely honors bestowed upon their so-called "native" subjects. As Swati Chattopadhyay observes, the initial phase of Calcutta's evolution into a major port and nerve center of Britain's Indian 
Empire marked a politically uncertain period when the newly minted Bengali elite realized that their "social visibility" was integral to maintaining their prosperity. Consequently, palatial residences and increasingly sumptuous puja celebrations became the norm, establishing complex spheres of sociability, cultural viability, and political negotiation ([32], p. 152). Within this context, the rajbari or palace emerged as the principal stage for the puja, and indeed, for the Durga pratima. It is also, as Ghosh suggests throughout Utsab, the stage for their decline.

An 1840 watercolor drawing by the English artist William Prinsep captures the atmosphere of a lavish Durga puja hosted in an unknown Calcutta palace [44] (Figure 10). Seated in a courtyard in front of the thakur dalan where the deity looms large as an ek chala Durga framed by the scalloped arches of the pavilion, a group of European men and women appear to watch a "nautch" (dance) hosted by the Bengali elite during Durga puja [45]. Clearly, the festival has ushered in a variety of performances that take place in the palace's courtyard. This is where the Bengali elite entertains and is, in turn, entertained. Today, only a handful of these families like the Shovabazar Debs continue the tradition of Durga puja, but without the fanfare of foreign attendees. In sharp contrast to the Debs and indeed to the scene depicted in Prinsep's drawing, other prominent Bengalis in nineteenth-century Calcutta like the patriotic Rani Rashmoni did not go out of their way to invite British guests to their Durga puja celebrations, while still others like the deputy magistrate Adharlal Sen focused instead on famous Bengalis like the celebrated mystic Sri Ramakrishna Paramhansa (also closely linked to Rani Rashmoni) whom he invited to his puja festivities [46].

Figure 10. William Prinsep, Europeans being Entertained by Dancers and Musicians in a Splendid Indian House in Calcutta during Durga Puja [44].

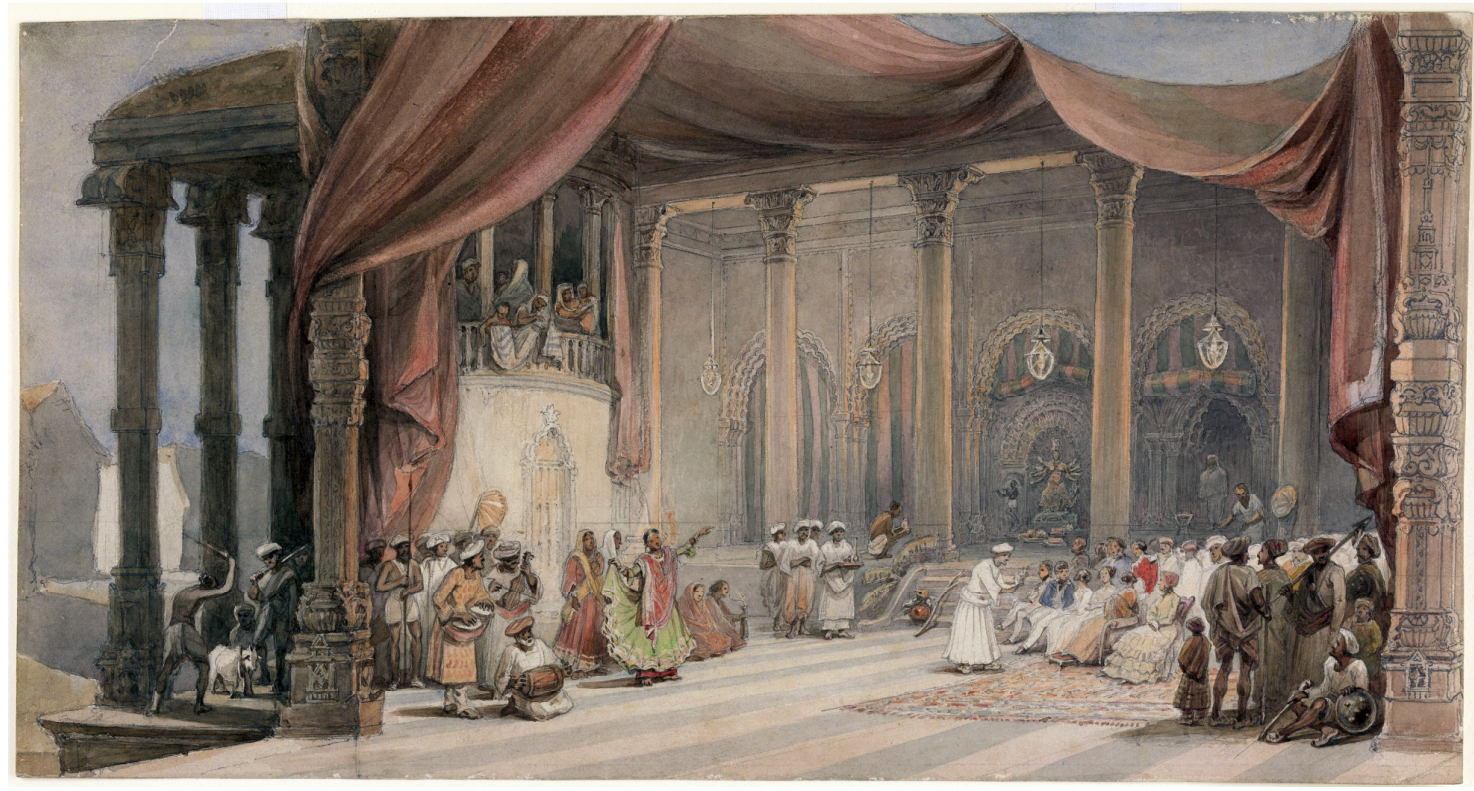

\section{Staging the Pratima, Framing Bhagabati}

By the early 1800s, the courtyard had evolved into a private space that could occasionally, as for instance, during Durga puja, become public. The focus on the interiority of the house was paramount in Calcutta's eighteenth-century Bengali palaces, an emphasis that shifted in the nineteenth century when the Bengali gentry, keen to advertise their wealth and status, gradually connected with the hustle 
and bustle of street life while also making the facades of their homes more elaborate. But the courtyard remained sequestered from public life even though it occasionally intersected with the public domain. Ghosh accentuates this network of private and public spheres by pausing outside the doorway just before entering the courtyard attached to the thakur dalan. As a garland of mango leaves and sola (pith) decorations is strung across the arched opening to the courtyard (a sign that festivities have begun), the viewer is made aware of the threshold that distinguishes the andar (interior) from the bahir (exterior) (Figure 6). Preparations are underway for panchami (fifth day) of the puja.

Like the chandelier, the Mughal inspired door with its scalloped arch is further material proof of the hybridized taste of affluent Bengalis who had embraced a mixture of Palladian and Mughal styles for their lavish homes (similar scalloped arches can be seen in Prinsep's drawing and Sydney Prior Hall's portrait of Sunity Devi) ([32], pp. 153-67). As such, it demarcates the mansion as a palace fit for a king with the merchant "raja" or "Rai Bahadur" at its helm. In sharp contrast to the borrowings from Mughal architecture or for that matter, from European neoclassical buildings which dotted the colonial landscapes of Bengal (most notably in Calcutta), the open courtyard into which the doorway leads is one of the oldest architectural forms in India that can be traced back to the Indus Valley Civilization (third millennium BC) [47]. Amorphous, malleable, and dynamic, this open enclosure was harnessed in the colonial rajbari as the principal gathering place for those who attend Durga puja, with the thakur dalan flanking its one end and raised above ground like a stage in an auditorium. Not surprisingly, like the courtyard in Prinsep's drawing, the courtyard in Utsab stages an array of performances documented by the camera-wielding Joy. Customary activities centered on the puja are captured to emphasize the full spectrum of the sights and sounds of the festival (Figure 11): sweeping the floor in anticipation of the ceremonies, gathering for the arati (the evening prayer/ritual), socializing, lighting lamps, and playing the dhak (drum).

Figure 11. Preparing the courtyard, screen grab, Utsab [1].

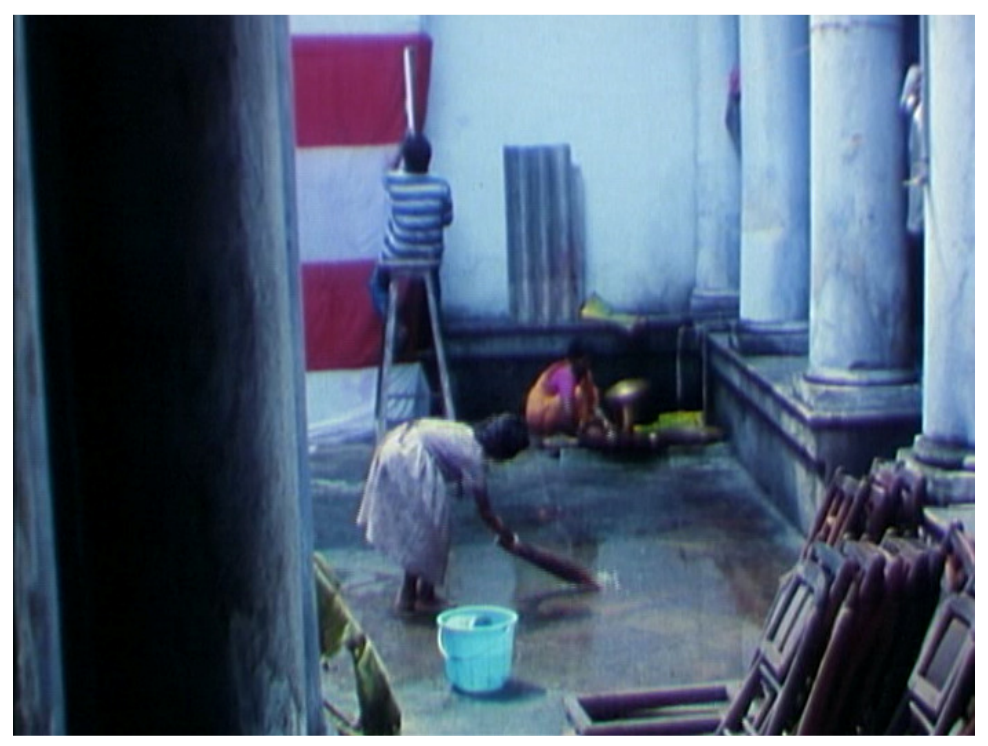

Thus, the festival effectively transforms the courtyard into the focal point of an explosion of sensory experiences. As sounds of the customary dhak, kashar ghonta (copper gong), and brass bells that accompany the puja spill into the rest of the house, the festival's primacy is inescapable no matter 
where one is located. When Ghosh, for instance, focuses on Bhagabati's sons, engaged in a tête-à-tête on one of the long balconies, the distinctive sounds of the musical instruments waft across, ensuring that the pratima darshan is always at the forefront, even when it does not dominate the screen (Figure 12). Pushed into the background, the deity's familiar contours are glimpsed through the smoky haze framed by the graceful curves of the cast iron railing. Visually too, Ghosh makes sure that the pratima is never far away, the haze illuminated by the golden light of lamps transforming her figure into a glowing ethereal presence that hovers in the cinematic space.

Such linkages and emphases intensify as the narrative progresses, especially because the film is shot entirely within the confines of a sprawling palace (no character is ever shown outside of the rajbari). Even the errant son-in-law Arun's hasty departure is never portrayed on the screen (by the film's end, he returns to the house). Occasionally a passing reference is made to the puja at a nearby club, a baroari (public or community) celebration whose festivities are rendered discernible through ritual sounds. Enmeshed in these different auditory experiences, the pratima's imagined "presence" and indeed the Durga festival come across as ubiquitous, all consuming, and limitless, even though Ghosh's camera is restricted to the house. The heavy emphasis on the interiors, especially the courtyard where Bhagabati and her family are both spectators and participants in their puja, reminds us that while the goddess may be sanctified both within the palace and outside of it, Utsab is primarily concerned with only one particular pratima and the lives of the characters engaged with her puja.

Figure 12. Bhagabati's sons on the balcony, Durga puja in the background, screen grab, Utsab [1].

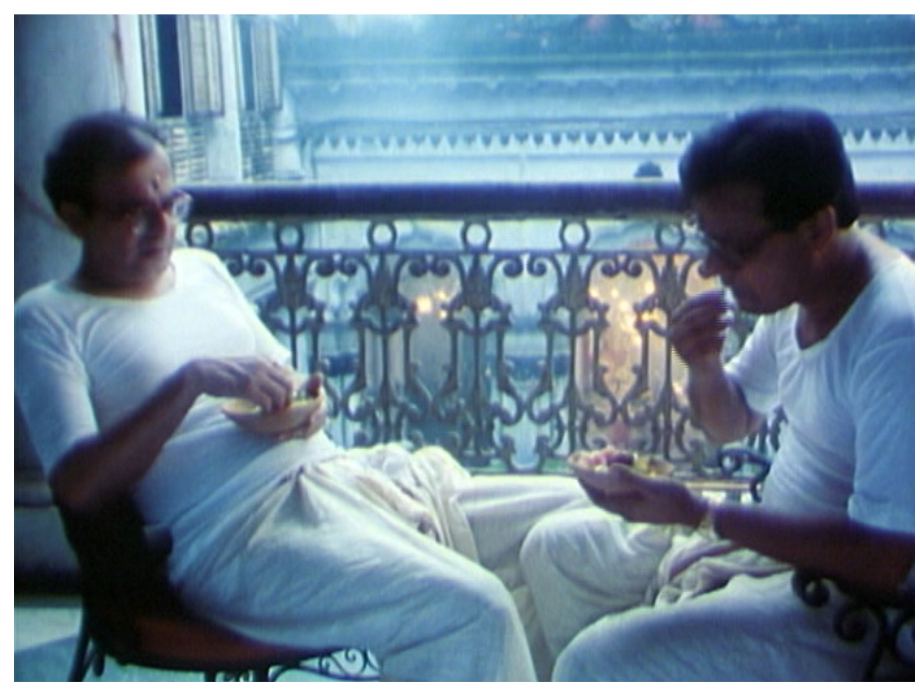

For his part, Ghosh deploys an ancestral pratima to highlight the fissures of human experience and the depths of human limitations. While Bhagabati the matriarch watches an arati in the courtyard, Keya, her younger daughter, observes the festivities from a sequestered vantage point in the verandah above (Figure 13). Seen alongside the dazzling splendor of the goddess so joyously celebrated as a mother and the conqueror of the evil asura (demon), a forlorn Keya's sorrow comes across as deep and inscrutable. Moreover, Ghosh modulates light and shadow to accentuate the young woman's vulnerability as she struggles with the desire to make peace with her husband [48]. His emphasis on the evening arati ensures that the scene is suspended in velvety pools of darkness that contrast sharply with the glittering chandeliers, the flickering flames of oil lamps, and the warm glow of the veil of 
ornamental lights strung along the balcony. It is through such contrasts that Ghosh situates the arati as a threshold of change and introspection. When juxtaposed with the glowing pratima, an idealized image whose controlled iconography is meant to be awe-inspiring, Keya emerges as a deeply flawed, unmistakably young woman coping with life's obstacles. As the film unfolds, it becomes increasingly clear that her character is the female counterpoint to Bhagabati's (complicated further by the latter being a living parallel to mother Durga). A youthful woman whose spontaneity is muted by the wisdom gained through life experience may seem at odds with the stoic elderly matriarch who has weathered life's challenges, but each represents a point of maturity in the course of womanhood whose evolution is clarified all the more by Keya's older sister Parul who represents the transition from youthfulness (Keya) to wisdom (Bhagabati).

Figure 13. Bhagabati watching the puja (left), Keya watching the puja (right), screen grabs, Utsab [1].
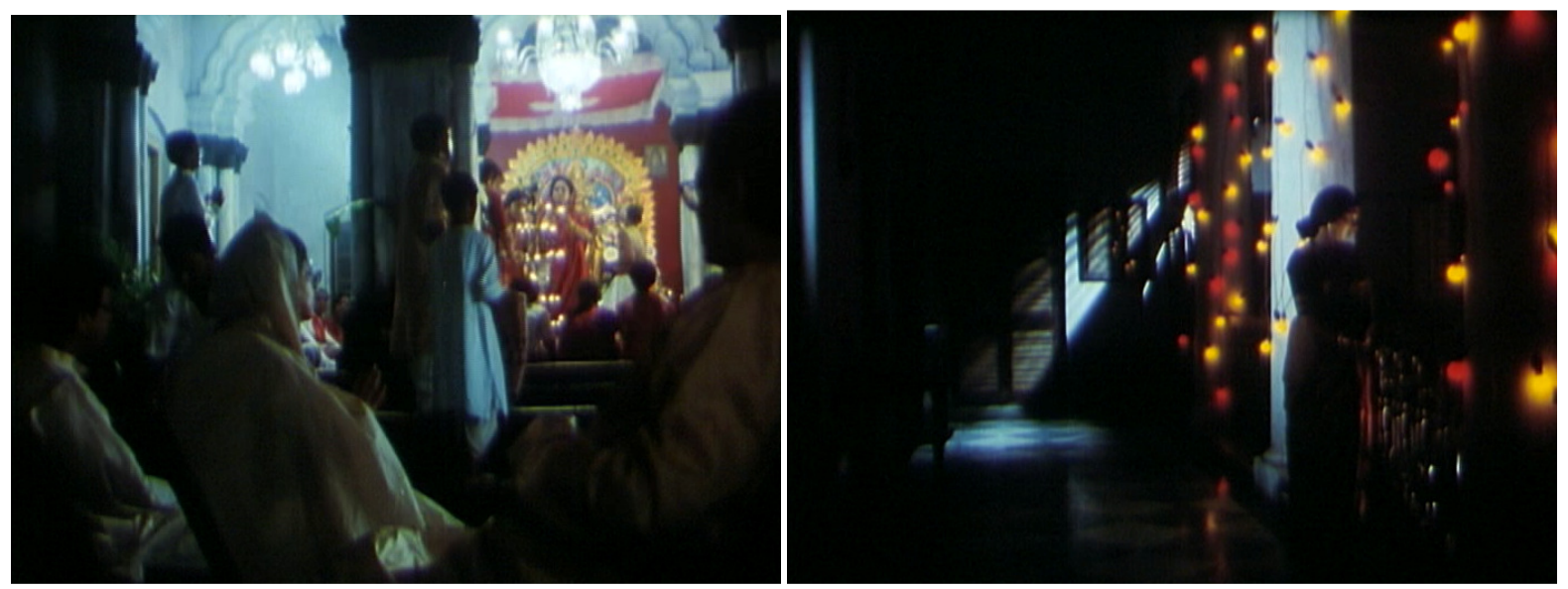

Visualizing corporeality means oscillating between the inanimate form of Durga and the living, breathing characters of the film, and between the (in)visibility of the pratima and the startlingly visible decay of a family's heritage. Key to this decline is Bhagabati, the last link to an era that Joy so proudly describes in the film's opening sequence, and whose aging figure is the opposite of the timeless pratima. A powerful source and site of historical memory, Bhagabati ensures the continuity of Durga puja as an ancestral festival. The pratima, on the other hand, enhances her frailty, its continuity as an iconic form underscoring her mortality. With her decline and demise, the annual darshan and puja will most likely come to an end. The closing sequence of the film gestures ever so subtly at this tragic possibility, with Ghosh juxtaposing the elderly Bhagabati with an image of her ancestral icon a few days after the festival has concluded. Arun has cued up the video that Joy has recorded so recently, and Bhagabati and Keya have settled down to watch the family documentary on a television set. As the video begins, we hear Joy narrating the history of the pratima and the rajbari, bringing us full-circle to the opening sequence of Utsab. Alerting us to the passage of time within the temporal framework of the film's narrative, such a cinematic gesture draws us into the making of history as a dynamic and often untidy process in which we, the viewers, are situated as active participants, not just as passive beholders. For we have been privy to the very creation of Joy's family video throughout Utsab. A family record or portrait of sorts, the documentary reveals the density of memories of the past that 
impinge upon the currency of the present, and the superfluity of the certainties of the present that make way for an unknown future.

The interwoven histories of the rajbari, the ancestral pratima, the puja's rituals, the fatal attraction between Joy and his cousin Shompa, and Joy's self-professed desire to record the "oriental exotica" of the puja, come together alongside the young filmmaker's reflections on his aunts and grandmother (noticeably, none of the men of the family are seen showcased in his video). Filmed shortly before Joy's departure for the United States, the family video renders the rehearsal of past and present family history all the more poignant, its very making and viewing embodying a trail of losses: the impending loss of Joy's participation in a family tradition, and finally, the irrevocable loss of an ancestral deity and an ancestral custom. Keeping this in mind, Ghosh draws us into the intimate circle of spectatorship in which Bhagabati, Keya, and Arun watch Joy's video. By emphasizing the technologies through which family history crystallizes, he also underscores the manner in which that history is stored, shared, and reviewed. The desire to keep memory alive through visual recording and oral history, even if that means holding onto selective memories, is ultimately anchored by the desire to hold onto corporeal identity as a familial narrative. Bodies are therefore shored up as indices of change, sensory experience, and lived memory. To this end, Joy's video is as much about documenting family history as it is about embedding himself within the creative processes of filmmaking as part of that family narrative. Thus, the camera functions as an extension of the self, enfolding Joy's role as an amateur filmmaker into the dynamics of family life while simultaneously granting him the opportunity to situate himself outside of those dynamics as a keen observer. Joy in front of the camera is both split apart from and linked with Joy behind the camera.

Swept up in the heady excitement of the changing frontiers of technology, Joy represents a new generation directly affected by the explosion of consumerism ushered in by India's free market economy launched in the 1990s. Filmed nearly a decade after the rise of a flourishing consumer culture in India, Utsab oscillates between Joy's wholehearted embrace of consumerism (no doubt a prelude to his entry into the United States) and Bhagabati's staunch adherence to her ancestral Durga puja, pratima, and palace. Like Keya, Joy is a counterpoint to Bhagabati, his youthful exuberance demarcating the impulsive desire to rush towards change as opposed to Bhagabati's calm acceptance of change. Acutely aware that her demise will result in the erosion of familial signposts and cultural referents to which she has been accustomed, the resolute matriarch surrenders to her future. Here too the pratima intervenes. Two scenes in particular come to mind: the first when Bhagabati is portrayed in the courtyard watching the customary evening arati, Ghosh positions her at a distance from the thakur dalan where the pratima can be seen in all her glittering glory (Figure 13). By contrast, in the closing sequence of Utsab, Ghosh draws the pratima into the more intimate spaces of the house by way of a television screen. When Durga's icon appears in Joy's video, Bhagabati touches her forehead in a gesture of prayer (Figure 14a, b). Both scenes demonstrate that Utsab and its emphasis on how the contours of family history are shaped and recorded for posterity are inseparable from the idioms of sacredness, devotion, and ritual so firmly anchored by the Durga pratima. 
Figure 14. (a) The pratima on the television screen (b) Bhagabati salutes Durga; screen grabs, Utsab [1].

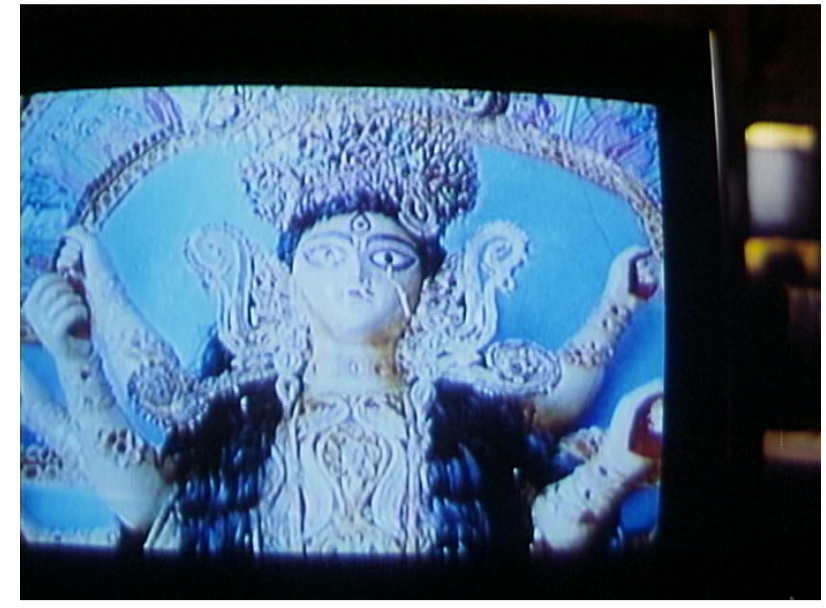

(a)

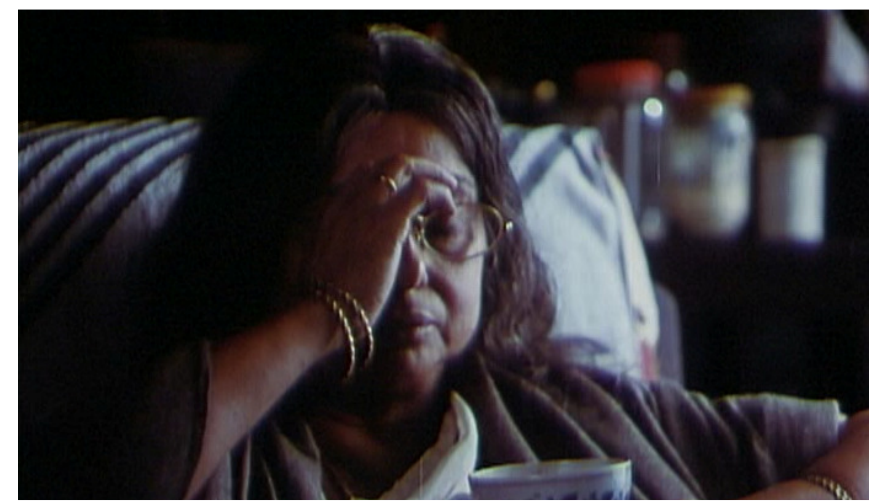

(b)

As importantly, Ghosh deploys the power of celluloid to accentuate these very idioms, thus emphasizing cinema's capacity to invoke darshan (seeing) as a doubly encoded epistemology: first in the act of looking at (reviewing) family history, and next in the act of looking at the pratima. Both types of darshan are interchangeable in Utsab, their interconnectedness sealed by the act of filming the pratima as part of the quotidian messiness of everyday domesticity and as part of a family's ancestral heritage. The screening of Joy's video on a television set opens up yet another space for darshan as Bhagabati and Keya (and we as viewers) engage with an ancestral icon within the context of current family history on a piece of electronic equipment. By enfolding the basic apparatuses of filmmaking and film viewing into the customary practice of darshan, Ghosh ensures that the rituals and symbols of a family Durga puja are now deposited into the technologies of television and video. To borrow from Sheila Nayar, "the sacred can be electronically mediated." ([11], p. 56).

Saluting the televised image of the pratima reveals a level of devotion that has crystallized from a thriving domain of media and entertainment ever since the late 1980s when the enormously popular television series Ramayan (1986-1988) and Mahabharata (1988-1990) based on two Hindu epics, generated what Purnima Mankekar describes as an "intense form of devotion or bhakti [produced] through the visual process of seeing or darshan." [49]. Drawing upon the popular iconography of 
calendar art, televised images of gods and goddesses created a new type of iconicity powered by electronic media, so much so that watching the Ramayan and Mahabharata became revered rituals much like a puja ([49], pp. 136-38). Here I want to turn to Christopher Pinney's discussion of "a zone of mutuality that encompasses devotee and image," a domain articulated by what he calls "corpothetics (sensory, corporeal aesthetics)" that links cinematic pleasure with the sacredness of an icon and the corporeal experience of a devotee [50]. Bhagabati touching her forehead while closing her eyes links tactility with prayer, and touch with sight, her gestures embodying Pinney's idea of "corpothetics," while also conveying her act of darshan that transforms a seemingly disembodied, flickering image of the pratima into a powerful node of veneration. In short, it is Bhagabati's devotion that collapses the divisions between the pratima on the television set and the pratima in the thakur dalan.

For Bhagabati, there is no distinction. When the goddess's face fills the television screen, the close-up shot intensifies the act of darshan as the viewer is pulled into the sacred space circumscribed by the pratima's sculpted figure. In this sense, the camera lens overcomes the limits placed on the devotee about how physically near or far one can be from the icon. The filmic representation of the pratima might be at its ephemeral best, an ungraspable image floating across a television screen; however, its proximity ensures that it is no less an object of veneration than the pratima in the dalan. But there is another enactment of "corpothetics" that underscores this act of darshan and indeed that of the entire film: this would be the darshan of the filmmaker who relies on the pratima to locate himself within the trajectory of Bengali cinema. In Utsab, worshipping the divine parallels venerating the very process of filmmaking. Both are presented as passionate forms of devotion. What then do we make of Ghosh filming the filmmaker?

\section{Filming the Filmmaker: A Self-Portrait}

In Utsab, Ghosh engages the sacredness of Durga puja by linking the pratima to other Durga icons in key Bengali films, most notably to Satyajit Ray's 1960 masterpiece Devi (The Goddess) and 1978 murder-mystery Joi Baba Felunath (The Elephant God), and Aparna Sen's critically acclaimed 1984 movie Paroma, which, like Utsab, begins with a photographer recording a lavish celebration of Durga puja at a colonial palace. In effect, Ghosh inserts himself into a formidable lineage of film-making in Bengal whose emphasis and occasional critique (especially by Ray) of high-caste Bengali Hindu traditions and beliefs centered on Durga puja accentuates the ambivalence of coming to terms with modernity. By this I mean the ambivalence of locating tradition, faith, devotion, and spirituality within a progressive, westernized, urban framework that has come to be defined as "being modern" in contemporary India. The character that best embodies this ambivalence is Joy, the amateur filmmaker touting a video camera (Figure 15) whose desire to record his family puja is underscored by his conscious decision to connect himself to Bengali cinema's stalwarts like Ray and Sen.

As such, Joy blurs the boundaries between reel and real life, between Joy the fictitious filmmaker and Ghosh the director. At times, with Joy's voice-over narration, Ghosh creates the illusion that the director's camera is in fact Joy's video camera. Keeping this in mind, it is tempting to interpret Utsab as an extended family video. Thus, it is through Joy's onscreen presence that Ghosh links himself to the cinematic icons Ray and Sen whom he writes into the film's script and visuals in very recognizable ways. 
Figure 15. Joy films the pratima with his video camera, screen grab, Utsab [1].

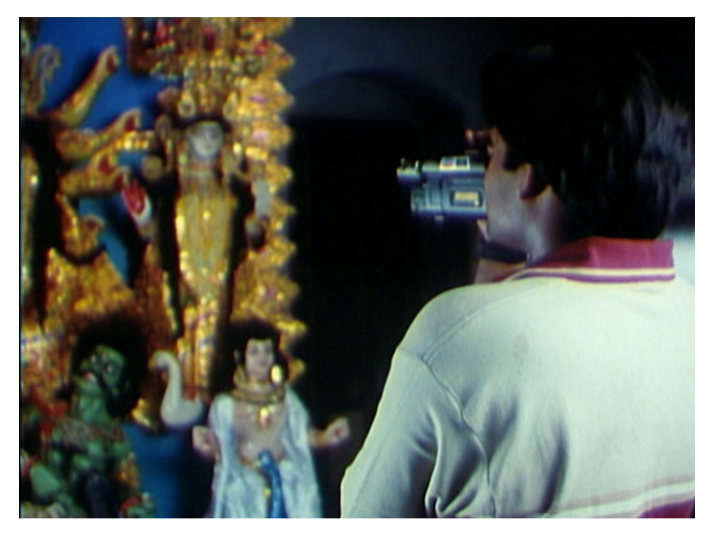

Three specific instances in Utsab stand out, all of which are inextricably linked with the pratima, and each of which references Ray and Sen. The first emerges in the opening sequence interspersed with the film's credits when Joy focuses his video camera (in reality Ghosh's camera) on a close-up view of the shining brass utensils objects used for his family puja, artifacts supposedly used by Ray in his film Devi (Figure 16). Ghosh continues to add to this myth as Joy goes onto narrate that Ray had visited the palace many years ago when his mother was a child. The second cinematic reference is Ray's Joy Baba Felunath (featuring the famous Bengali detective Feluda) whose influence is indisputable in the scene in which Joy videos Banshida's conversation with Bumba while decorating the pratima (Figure 7). "Banshida, as usual, is yet to complete the pratima. He has been busy chatting with Bumba. It is just like the opening scene from Joy Baba Felunath.” [51]. Bumba, brandishing a toy gun, and Banshida dutifully putting the finishing touches to the gods, are captured in a series of visuals borrowed directly from Ray's film. The third point of reference, Aparna Sen's Paroma, is invoked during sindoor khela (playing with vermilion) (Figure 9).

Figure 16. Puja utensils used by Satyajit Ray, screen grab, Utsab [1].

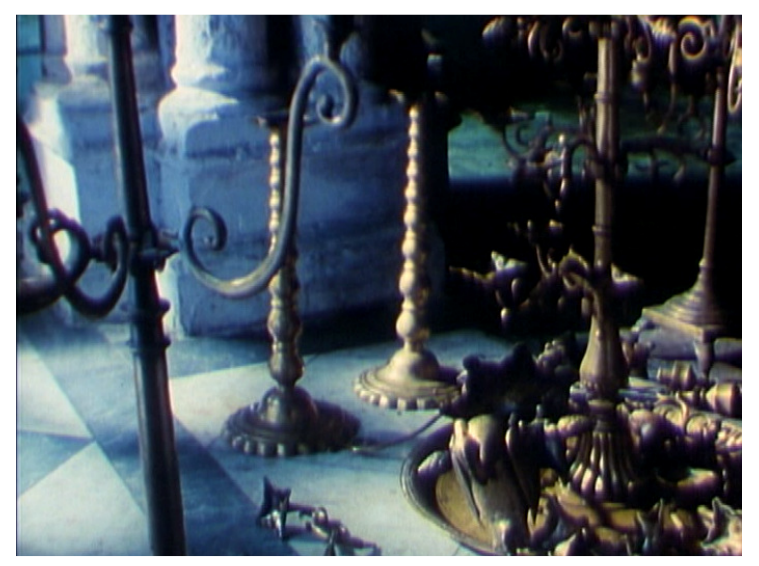

Such visual engagements with the pratima also hone in on the viewer's capacity to connect the dots between Ghosh, Ray, and Sen's body of work, revealing the expectations Ghosh has of his audience: educated and well versed enough in Bengali art (versus commercial or mainstream) cinema so as to discern the visual quotations he inserts into Utsab. In the event the viewer fails to recognize those quotations, Ghosh bolsters the scene with verbal directives to Ray and Sen. What matters is that these references are articulated by how Ghosh frames the pratima in ways in which the viewer recognizes 
the sliding back and forth between Utsab, and Ray and Sen's movies. By embedding the indisputable appeal of Durga to the Bengali psyche in Utsab, an appeal that for their part Ray and Sen also understood and deployed, Ghosh forges an alliance with the pratima to create a timeless appeal for his movie and for himself. The fixed iconography of Durga not only enhances the divinity of the goddess, it also ensures a permanent place for Ghosh among some of the most thought provoking Bengali directors to have emerged since the 1960s.

By the same token, the pratima sanctions Ghosh's deep-seated Bengali identity and instinctive feel for the local nuances that underscore his film. From this perspective, the desire to inscribe oneself as a noteworthy Bengali filmmaker (not just an Indian one) threads its way through Utsab, subtly drawing our attention to the invisible Ghosh whenever Joy appears on the screen with this camera. When Utsab's opening sequence is screened as Joy's family video on the television set and subsequently enfolded into the movie's narrative projected on the big screen, the boundaries between Ghosh and the fictitious young filmmaker are dissolved. A metonymic reminder of Ghosh and his camera, Joy's video camera not only extends the possibility of looking past the human body; it also deposits Ghosh into Utsab. Being Joy is therefore about being Ghosh, and this convergence alone sanctions the camera as the principal tool through which Ghosh mediates his invisibility as a self-portrait embedded in the film. Such multilayered corporeality in Utsab compels us to look past the tangible body to question what other bodies lurk beyond those we see and what their apparent invisibility might suggest.

In visual terms, a portrait is fundamentally a likeness based on a biological body. By registering his portrait through Joy's filmmaking aspirations, Ghosh, however, suggests that it is not just the corporeal, but also intangibles like the performance of an individual's desires, hopes, and longing through which corporeality is keenly felt, that are capable of invoking a recognizable figure. Buried in more complex layers of human character than a conventional visual portrait might represent, corporeality is articulated as much by emotions and experiences, as it is by the sheer phenomenon of being a physical body subject to biological change. Along these lines, cinema itself is suspended between the physical and the phenomenological, and also between the material and the emotional, such that fictitious characters come alive as portraits in the minds of the audience. At a fundamental level, the viewer has to relate to these corporealities projected on the screen. Bhagabati appeals because some aspect of her touches a chord in the audience, or recalls another real-life individual whom she resembles (the same can be said for the other characters that appear in Utsab). Being Joy/Ghosh therefore invites us to contemplate the director not as a celebrity, but as yet another Bengali in tune with his heritage of Durga puja.

Seen another way, the pratima renders the very process of filmmaking embedded in Joy's figure, as Ghosh's darshan to both the goddess and his craft. The principal instrument to facilitate this doubly encoded act of darshan (seeing) is the camera, which not only directs the gaze towards the pratima, it also emphasizes the extent to which visual technologies are now an integral part of the rituals of worship in contemporary India. That said, Ghosh's darshan remains open-ended and malleable. While it might draw upon the basic desire to "see" (and thus venerate) the pratima, it nevertheless enables other human desires such as betrayal, regret, and attraction to enter the space of darshan. Such is the power of film. It can crystallize a particular mode of being (devotion, for instance) while making room for other corporeal interventions. By the same token, it can merge two different corporealities-in this instance, Joy's with Ghosh's-while also gesturing at their divergent ontologies and temporalities within the same fictitious space. 


\section{Conclusions}

For Ghosh, history matters. At a fundamental level, the cultural flow of history is determined by corporeality, mediated in Utsab through the dialectic between the pratima and the occupants of a colonial palace. Surrounded by material artifacts that represent a prosperous colonial past strangely out of place in a post-Independence era, these characters also suggest that Bengal's history once defined by its upper-caste, upper-class families is now defunct. In Utsab, bodies are visualized as genteel yet drab, their visual dullness reinforcing their narrative of decline, with Bhagabati as the most visually compelling figure whose widowhood enshrined in white Bengal cotton saris foreshadows yet another loss - the painful prospect of losing her house and her Durga puja. The thick layers of time and space that seem so reassuringly familiar when anchored by her presence can be equally discomfiting when they are fated to be dismantled. Loss is ultimately articulated by the corrosion of corporeal identity that is in turn defined by the very spaces and places within which it grows and flourishes, and the objects with which, and through which, it evolves. Thus, Bhagabati is incomplete without her pratima or for that matter, without her palace.

For history to unfold, the difficulties of loss have to be buried in the contours of change. In Utsab, Ghosh brings us to the very threshold of transition where the narrative's characters have to disperse at the festival's end. All we are left with is the keen sense that change is not only inevitable, it will be impossibly spectacular when it happens, for the grandeur of the palace, the puja, and the pratima ensure a sweeping obliteration of ancestral heritage, material history, and a sense of belonging. Corporeality can only be enhanced by such deep and profound transitions, but only for a short while before its relevance too is flattened out in time. Like the pratima whose lavishly ornamented clay figure displayed during the puja is immersed in a river at the conclusion of the festival, the corporeal is equally fragile and capable of being diluted or for that matter, erased. Perhaps it is this sense of futility that Ghosh wished to pinpoint in Utsab, rendering his film a reflection on the ultimate fate of corporeality: death and the irrelevance of loss.

\section{Conflicts of Interest}

The author declares no conflict of interest.

\section{References and Notes}

1. Rituparno Ghosh. Utsab [film]. $35 \mathrm{~mm}$ color film. Directed by Rituparno Ghosh. India: Cinemawalla/Shemaroo Video Private Limited, 2004. DVD.

2. For a useful overview of the legend of Durga, see Sukumari Bhattacharji. Legends of Devi. Calcutta: Orient Longman, 1995, pp. 30-44.

3. Although I use the name "Kolkata" for most of my article, I use "Calcutta" when referring to the city's colonial era. Calcutta's name was changed to "Kolkata" in 2001.

4. Anjan Ghosh. "Spaces of Recognition: Puja and Power in Contemporary Calcutta." Journal of South African Studies 26, no. 2 (2000): 289, note 1. As Ghosh notes, the term puja can be applied to both "public celebrations" and to more private, domestic rituals of "worship and devotion". For 
an excellent overview of the public and private celebrations of Durga puja, see Jyotirmoyee Sarma. "Puja Associations in West Bengal." The Journal of Asian Studies 28, no. 3 (1969): 579-94.

5. The term zamindar can be broadly defined as a wealthy landowner who collected taxes from peasants.

6. Sri Sri Durgamata. Published by Ghosh Mazumdar and Company, Calcutta. H. Daniel Smith Poster Archive, Special Collections Research Center, Syracuse University Libraries. Poster Binder 10, volume 1, 0421a.

7. Tapati Guha-Thakurta. "From Spectacle to Art: The Changing Aesthetics of Durga Puja in Contemporary Kolkata." Marg 61, no. 2 (2009): 54-81.

8. This advertisement was published in a special brochure. "Security Advisory for Citizens." The Times of India, October 2013, p. 15.

9. Yi-Fu Tuan. Space and Place: The Perspective of Experience. Minneapolis: University of Minnesota Press, 1977, p. 162.

10. Rachel Dwyer. Filming the Gods: Religion and Indian Cinema. New York: Routlege, 2006, p. 159.

11. Sheila J. Nayar. The Sacred and the Cinema: Reconfiguring the 'Genuinely' Religious Film. London: Continuum, 2012, pp. 5-6.

12. Steven Lubar, and W. David Kingery. "Introduction." In History from Things: Essays on Material Culture. Edited by Steven Lubar and W. David Kingery. Washington: Smithsonian Institution Press, 1993, p. viii. Italics in the quotation are mine.

13. Supriya Chaudhuri. "Phantasmagorias of the Interior: Furniture, Modernity, and Early Bengali Fiction." Journal of Victorian Culture 15, no. 2 (2010): 173. See also Walter Benjamin. "Paris, the Capital of the Nineteenth Century." In Selected Writings. Edited by Michael Jennings. Cambridge, MA: Harvard University Press, vol. 3, 2002, pp. 32-49. For a useful overview of the social atmosphere and cultural settings of nineteenth-century Calcutta, see Sumanta Banerjee. The Parlour and the Streets: Elite and Popular Culture in Nineteenth-Century Calcutta. Calcutta: Seagull Books, 1989, pp. 147-98.

14. The chandelier can also be read as a visual tribute to Satyajit Ray's 1958 Jalsãghar (The Music Room), a movie about a proud and spendthrift zamindar (landowner) who wastes away his ancestral wealth while neglecting his family. Ray used the magnificent crystal chandelier to highlight the brittleness of the zamindar's pride and the poignancy of his impending loss. Rituparno Ghosh was deeply influenced by Ray's films.

15. Marcia Pointon. Brilliant Effects: A Cultural History of Gem Stones and Jewellery. London: Yale University Press, 2009, p. 4.

16. Partha Chatterjee. "Colonialism, Nationalism, and Colonialized Women: The Contest in India." American Ethnologist 16, no. 4 (1989): 625.

17. Sonia Nishat Amin. The World of Muslim Women in Colonial Bengal, 1876-1939. Leiden: E. J. Brill, 1996, p. 133.

18. Rochona Majumdar. Marriage and Modernity: Family Values in Colonial Bengal. Durham: Duke University Press, 2009, p. 143.

19. Nandi Bhatia. "Fashioning Women in Colonial India." Fashion Theory: The Journal of Dress, Body \& Culture 7, no. 3/4 (2003): 327-44.

20. Sydney Prior Hall. The Maharani of Cooch Behar. Oil on panel, 1887. Supplied by Royal Collection Trust (C Her Majesty Queen Elizabeth II, 2014, RCIN 403601. 
21. Sarala Devi Chaudhurani. The Many Worlds of Sarala Devi: a Diary Translated from the Bengali Jeevaner Jharapata. Translated by Sukhendu Ray. New Delhi: Social Science Press, 2010, p. 99. Hamilton and Company was among the earliest British jewelers and silversmiths to establish a thriving business in colonial Calcutta (their presence in the city can be dated back to the opening decades of the nineteenth century). Jewelry "made by native workmen under European supervision" for the firm was subsequently exhibited in the Calcutta Court of the Calcutta International Exhibition (1883-1884). For more information about this and other jewelry exhibitions organized by Hamilton and Company, see Official Report of the Calcutta International Exhibition, 1884-1884: Compiled Under the Orders of the Executive Committee. Calcutta: Bengal Secretariat Press, 1885, p. 117. See also, Vidya Dehejia. "Calcutta Silver and Rural Scenes." In Delight in Design: Indian Silver for the Raj. Contributed by Vidya Dehejia, Dipti Khera, Yuthika Sharma and Wyngard R.T. Wilkinson. Ahmedabad: Mapin Publishing, 2008, p. 185. For a very accessible overview of colonial Calcutta, see Dhrubajyoti Banerjea. European Calcutta: Images and Recollections of a Bygone Era. Kolkata: UBS Publishers, 2005.

22. Sarala Devi Chaudhurani. The Many Worlds of Sarala Devi: A Diary Translated from the Bengali Jeevaner Jharapata. Translated by Sukhendu Ray. New Delhi: Social Science Press, 2010, p. 99. For an excellent overview of Sarala Devi and her contributions to the Bengali intellectual and cultural milieu of Kolkata, see Bharati Ray, "Introduction," Sarala Devi, pp. 1-26.

23. Bhabanicharan Bandhyopadhyay quoted in Sudeshna Banerjee. Durga Puja: Yesterday Today and Tomorrow. New Delhi: Rupa and Company, 2006, p. 41.

24. Mukunda Das quoted in Tanika Sarkar. "Nationalist Iconography: Image of Women in 19th Century Bengali Literature.” Economic and Political Weekly 22, no. 47 (1987): 2013.

25. Jasodhara Bagchi. "Representing Nationalism: Ideology of Motherhood in Colonial Bengal." Economic and Political Weekly 25, no. $42 / 43$ (1990): WS65.

26. See also Srabashi Ghosh. "Birds in a Cage": Changes in Bengali Social Life as Recorded in Autobiographies by Women.” Economic and Political Weekly 21, no. 43 (1986): WS88-WS96.

27. Charles Coleman. The Mythology of the Hindus: With Notices of the Various Mountain and Island Tribes Inhabiting the Two Peninsulas of India and the Neighbouring Islands, and an Appendix Comprising the Minor Avatars and the Mythological and Religious Terms, \&c, \&c of the Hindus. London: Parbury, Allen, \& Co., 1832.

28. Tithi Bhattacharya. "Tracking the Goddess: Religion, Community, and Identity in the Durga Puja Ceremonies of Nineteenth-Century Calcutta.” The Journal of Asian Studies 66, no. 4 (2007): 938-39.

29. For a useful overview of some of these mansions, see Joanne Taylor. The Forgotten Palaces of Calcutta. New Delhi: Niyogi Books, 2007; Krishna Dutta. Calcutta: A Cultural and Literary History. Oxford: Signal Books, 2003, pp. 33-57.

30. Bell Hooks. Yearning: Race, Gender and Cultural Politics. London: Turnaround, 1991, p. 147.

31. Bhagabati is dressed like a traditional Hindu widow in a white cotton sari.

32. A thakur dalan is a pavilion reserved for displaying a deity. By the middle of the nineteenth century, it was a standard feature in Calcutta palaces. For more about this structure, see Swati Chattopadhyay. Representing Calcutta: Modernity, Nationalism, and the Colonial Uncanny. London: Routledge, 2006, pp. 154-57; Martin Beattie. 'Hybrid Identities: 'Public' and 'Private' 
Life in the Courtyard Houses of Barabazaar, Kolkata, India." In Constructing Place: Mind and Matter. Edited by Sarah Menin. London: Routledge, 2003, p. 156.

33. Rachel Fell McDermott. Revelry, Rivalry, and Longing for the Goddesses of Bengal: The Fortunes of Hindu Festivals. New York: Columbia University Press, 2011, pp. 3, 41. See also Tithi Bhattacharya's excellent discussion of the urban Durga puja in colonial Calcutta in "Tracking the Goddess: Religion, Community, and Identity in the Durga Puja Ceremonies of Nineteenth-Century Calcutta." pp. 933-40.

34. The idea of an invented tradition emerges from Benedict Anderson's now classic. Benedict Anderson. Imagined Communities: Reflections on the Origin and Spread of Nationalism. London: Verso, 2006. For a discussion of traditions invented by British colonials, see David Cannadine. Ornamentalism: How the British Saw their Empire. Oxford: Oxford University Press, 2001.

35. It is tempting to speculate that the beginning of Utsab is Ghosh's personal tribute to the goddess Durga, and to the very processes of veneration that transform a clay figure into an iconic "living" goddess lodged in deep belief systems and rituals.

36. An ek chala Durga comprises of all five deities (Durga, Ganesh, Kãrtik, Saraswati, and Lakshmi) and their vahanas (vehicles) beneath one continuous arch.

37. For more about clay images of Durga, see Susan S. Bean. "Vessels for the Goddess: Unfired-Clay Images of Durga in Bengal." In The Goddess Durga: The Power and the Glory. Edited by Pratapaditya Pal. Mumbai: Marg Publications, 2009, pp. 38-53.

38. Keya Ganguly. Cinema, Emergence, and the Films of Satyajit Ray. Berkeley: University of California Press, 2010, p. 112.

39. Sumathi Ramaswamy. "Maps, Mother/Goddesses, and Martyrdom in Modern India." The Journal of Asian Studies 67, no. 3 (2008): 827.

40. Bankimchandra Chattopadhyay and Sister Nivedita quoted in Jasodhara Bagchi, "Representing Nationalism: Ideology of Motherhood in Colonial Bengal," p. WS69.

41. The number 108 bears a special significance in Durga puja: 108 lamps are lit during Sandhi puja (evening prayers) between the eighth and ninth days of the festival when Durga is invoked as a warrior goddess. In the Ramayana, Lord Rama worships Durga, with 108 lotuses and 108 lamps, before embarking on his battle with Ravana. For more about Sandhi puja, see Kanai L. Mukherjee, Bibhas Bandyopadhyay, Aloka Chakravarty, and Arunkanti Banerjee. New Age Purohit Darpan: Durga Puja. Nashville, TN: Association of Grandparents of Indian Immigrants, 2013, pp. 169-71.

42. Anjan Ghosh. "Spaces of Recognition: Puja and Power in Contemporary Calcutta." Journal of South African Studies 26, no. 2 (2000): 289.

43. Swati Chattopadhyay. Representing Calcutta: Modernity, Nationalism, and the Colonial Uncanny. London: Routledge, 2006, p. 152.

44. William Prinsep. Europeans Being Entertained by Dancers and Musicians in a Splendid Indian House in Calcutta during Durga Puja, 1840. Watercolor, 1840 (C) The British Library Board, WD 4035.

45. For more about Prinsep, see Arthur Charles Staples. "Memoirs of William Prinsep: Calcutta Years, 1817-1842.” Indian Economic Social History Review 26, no. 61 (1989): 61-79. See Tithi Bhattacharya's discussion of the "nautch" during Durga puja in "Tracking the Goddess: Religion, Community, and Identity in the Durga Puja Ceremonies of Nineteenth-Century Calcutta.”, pp. 944- 
46. It is worth noting that an ivory Durga pratima made on a much smaller scale than the pratima depicted in Prinsep's drawing, was auctioned in 2010 at Christie's in New York City. Made in 1836 by "Toolsee Ram" (Tulsi Ram), it was gifted by Mubarak Ali Khan, Nawab of Bengal, to King William IV. A few decades later, Queen Victoria loaned the icon to the Manchester Art Treasures Exhibition of 1857. I am grateful to Chitralekha Pal for bringing this object to my attention. Available online: http://www.christies.com/lotfinder/sculptures-statues-figures/an-ivoryaltarpiece-of-durga-mahishasuramardini-india-5293926-details.aspx (accessed on 16 November 2013). Two other similar unsigned examples of ivory Durga icons are in the collection of the Victoria and Albert Museum (London): one was displayed at the Great Exhibition of 1851 in London (museum number 1070-1852), while the other was exhibited at the Exposition Universelle of 1855 in Paris (museum number 02466 IS). See Pratapaditya Pal. "The Mystery of Tulsiram's Durga and Ivory-Carving of Murshidabad." In Murshidabad: Forgotten Capital of Bengal. Edited by Neeta Das and Rosie Llewellyn-Jones. Mumbai: The Marg Foundation, 2013, pp. 106-22.

46. "Today is Mahasthami [eighth day of the Durga festival], 28 September 1884. Sri Ramakrishna is going to Calcutta on a devotional tour of pratima darshan [worshiping the Durga pratima]. Festivities are in full swing at Adhar's house. Ramakrishna has been invited for three days of the puja." Mahendranath Gupta. Sri Sri Ramakrishna Kathamrita. Kolkata: Udbodhan Karyalaya, 1990, p. 691. Translation is mine. For a discussion of the courtyard and the hybrid style of architecture in these mansions see Swati Chattopadhyay, Representing Calcutta: Modernity, Nationalism, and the Colonial Uncanny, pp. 153-67.

47. For a useful discussion of the courtyard as an architectural form in India, see Amita Sinha. Landscapes in India: Forms and Meanings. Boulder: University Press of Colorado, 2006, pp. 157-65.

48. At another level, the scene recalls one of Ghosh's later films Antar Mahal (2005), in which a newly married bride sequestered in the antar mahal (inner chamber) of a magnificent palace (not unlike Bhagabati's) steals a glance at a handsome sculptor coaxing clay into the form of Durga in the courtyard. Whether he intended to quote himself or not, in Antar Mahal, Ghosh situates a young, seemingly disempowered woman alongside her opposite, the triumphant, female divinity of Durga, brimful of shakti (power). Somewhere in between, a male protagonist punctuates this juxtaposition, be it in the attractive artist in Antar Mahal or an estranged husband in Utsab. Thus, the Durga pratima is no longer just a deity exalted for her puja; she is also the locus of unfulfilled desire and longing for key characters in each film.

49. Purnima Mankekar. "Epic Contests: Television and Religious Identity in India." In Media Worlds: Anthropology on New Terrain. Edited by Faye D. Ginsburg, Lila Abu-Lughod and Brian Larkin. Berkeley: University of California Press, 2002, p. 137.

50. Christopher Pinney. 'Photos of the Gods': The Printed Image and Political Struggle in India. London: Reaktion Books, 2004, pp. 193-94. See also in Rachel Dwyer, Filming the Gods: Religion and Indian Cinema, p. 19.

51. Translation is mine.

(C) 2014 by the author; licensee MDPI, Basel, Switzerland. This article is an open access article distributed under the terms and conditions of the Creative Commons Attribution license (http://creativecommons.org/licenses/by/3.0/). 